9. Литвинов О.М. Кримінологічна стратегія як компонент стратегії національної безпеки України. Право і Безпека. 2010. № 3. С. 137-141. URL: http://nbuv.gov.ua/UJRN/ Pib_2010_3_31.

10.-Миськевич Т. Стратегія антикорупційної політики України. Громадська думка про правотворення (Інформаційно-аналітичний бюлетень на базі оперативних матеріалів). № 10 (154). 2018. C. 10-14. URL: http://nbuviap.gov.ua/images/dumka/2018/10.pdf.

11. Тактика розслідування злочинів. Поняття криміналістичної тактики, іï значення в діяльності приватних детективів та детективних агентств. URL: http://www.detektiff.com. ua/rozsliduvannya-zlochiniv/.

12. Туєв О. Кримінологічна політика і стратегії протидії рейдерству. Публічне право. 2012. № 4. C. 185-190. URL: http://www.yourfuture.org.ua/ua/pb/2012/8/Tuev.pdf.

13.Шрамко С.С. Поняття та специфіка стратегії зменшення можливостей вчинення злочинів. Вісник Асоціації кримінального права України. 2017. № 1 (8). С. 193-202. URL: http://nauka.nlu.edu.ua/wp-content/uploads/2017/07/11_Shramko.pdf.

РОМАНЮК Ю. П., студент V курсу

(Навчально-науковий інститут права Університету державної фіскальної служби України)

DOI https://doi.org/10.32842/2078-3736-2019-6-2-15

\title{
ПРАВОВЕ РЕГУЛЮВАННЯ ПУБЛІЧНОГО КРЕДИТУ
}

У статті розглянуто сутність правового регулювання публічного кредиту, встановлені основні принципи, ідеї та чинники, які зумовлюють необхідність отримання публічного кредиту, а також визначено основні засади кредитування в Україні. Встановлено низку чинних нормативно-правових актів, які безпосередньо окреслюють тлумачення публічного кредиту та за допомогою встановлених норм регулюють публічний кредит.

Висвітлюються питання законодавчої бази, яка регулює саме в даний час відносини публічного кредиту та визначається ефективність чинної нормативно-правової бази щодо регулювання питання публічного кредиту в Україні. Наводиться низка визначень публічного кредиту та кредиту зокрема. Досліджуються методи, які виступають засобом пізнання публічного кредиту. Розглянуто питання щодо зобов'язання, позики та державного боргу.

У статті також висвітлюються теоретичні аспекти публічного кредиту, наводиться низка заходів та методів, які застосовуються в умовах сьогодення для надання публічного кредиту, звертається увага на несприятливу ситуацію в законодавчому врегулюванні питань із надання кредиту.

Чітко зазначається, що законодавство України натепер не може регулювати питання публічного кредиту, адже нема чіткого та єдиного нормативно-правового акта, який висвітлював би дане питання повністю, а не через відсилочні норми до іншого нормативного акта.

Зазначається, що правове регулювання публічного кредиту дуже важливе як для держави, так і для фізичних та юридичних осіб. Висвітлюється

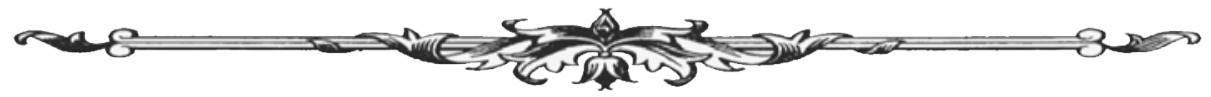


питання щодо встановлення найефективнішого механізму правового регулювання публічного кредиту шляхом ухвалення єдиного систематизованого нормативного акта, який би чітко врегулював проблематику публічного кредиту та зосередив у собі всі основоположні засади, ідеї, принципи, завдання, сторони публічного кредиту, а також санкції за порушення тих чи інших вимог, які мають бути належно висвітлені в певному нормативному акті.

Ключові слова: публічний кредит, державний бюджет, кредитування, кредитні відносини, нормативно-правова база публічного кредитування, зобов'язання, грошово-кредитна політика, позика, грошові кошти.

The article deals with the essence of legal regulation of public credit, establishes basic principles, ideas and conditions that make it necessary to obtain public credit, and defines the basic principles of crediting in Ukraine. A number of valid legal acts have been established, which directly outline the interpretation of the public credit and regulate the public credit with the help of the established norms.

The issues of the legislative framework that regulates the current relationship of public credit and determine how effectively the current legal framework regulates the issue of public credit in Ukraine are covered. There are a number of definitions of public credit and credit in particular. Methods that serve as a means of learning about public credit are established. Also, when considering the subject of public credit, it is impossible not to pay attention to the coverage of issues related to obligations, loans and public debt.

The article also covers the theoretical issues of public credit, outlines a number of measures and methods used in the current context for public credit, and draws attention to the adverse situation in the legislative regulation of credit issues.

It is clearly stated that the legislation of Ukraine, at present, is not able to regulate the issue of public credit, because there is no clear and uniform legal act that would cover this issue in full, and not having reference norms to another normative act.

It is noted that legal regulation of public credit is very important, both for the state and for individuals and legal entities in particular. The question of establishing the most effective mechanism for legal regulation of public credit, which should occur by adopting a single systematized regulatory act, which clearly implements the regulation of the problem of public credit and focuses on all the basic principles, ideas, principles, tasks, parties and public credit for violations of certain requirements, which should be clearly stated in a specific legal act.

Key words: public credit, state budget, lending, credit relations, legal framework of public lending, liabilities, monetary policy, loan, cash.

Вступ. У сучасному світі таке явище, як публічний кредит, характерне для всіх країн без винятку. Використання публічного кредиту пояснюється необхідністю усунути суперечності між неухильно зростаючими потребами держави у фінансових ресурсах і обмеженими можливостями отримання доходів, які формують державний бюджет країни.

Держава змушена позичати кошти у власного населення та різних організацій, а також в іноземних держав і суб'єктів міжнародного права.

Низка науковців дотримуються думки, що продуктивним засобом подолання бюджетного дефіциту завжди був державний кредит, який проявляється у формі беземісійного методу мобілізації грошових коштів разом із підвищенням податкових ставок і емісій.

Варто зазначити, що ефективнішим із цих способів є державний кредит, адже саме він дозволяє акумулювати досить велику суму грошових коштів за короткий термін без загрози інфляції, яка цілком вірогідно відбулася б за емісією.

Саме тому вже чимало років наша країна виступає позичальником коштів у фізичних та юридичних осіб для погашення боргу держави.

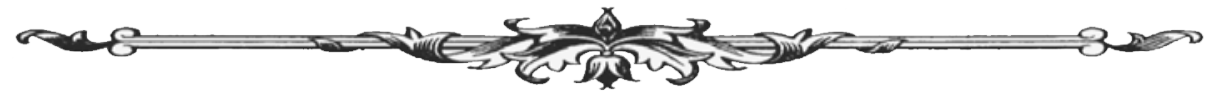


Питання правового регулювання публічного кредиту досліджували такі вчені, як: О. Зайцев, А. Щетин, Н. Лубкей, Б. Івасів, А. Демків, О. Давидов, Я. Зінченко, В. Геращенко, О. Величко, Б. Скоков, Ю. Потійко, О. Юсупов.

Постановка завдання. Мета статті полягає в обгрунтуванні теоретичних засад публічного кредиту, дослідженні правового регулювання питань публічного кредиту й аналізі етапів розвитку публічного кредиту, оскільки наявність інституту публічного кредиту зумовлена необхідністю фінансування державних видатків, що постійно зростають.

Результати дослідження. Позитивним явищем для розвитку суспільства та конкретного індивіда в Україні є надання кредиту за умовами чинного законодавства.

Зауважимо, що перехід ринкової економіки до розвинених ринкових відносин багато в чому залежить від створення належних умов функціонування суб'єктів господарювання та правового забезпечення ринкових реформ щодо дотримання ними вимог чинного законодавства.

Сьогодні державний кредит є однією з основних складових частин фінансової системи сучасної держави, ефективне використання якого є результатом розвитку пріоритетних сфер діяльності держави, інноваційного процесу суспільства, але насамперед це гальмування інфляційних процесів та підтримання балансу державного бюджету.

Варто визнати, що хоча основні доходи державного і місцевих бюджетів мобілізуються за допомогою основного - обов'язкового методу збору фінансових ресурсів, однак цих коштів жодній державі у світі не вистачає, тому більшість держав, Україна також, активно вдається до методу добровільної мобілізації тимчасово вільних грошових засобів фізичних і юридичних осіб. Цей вид фінансових правовідносин є публічними відносинами, які випливають із державного кредиту.

Варто зазначити, що кредит (від лат. credere - «довіряти», credo - «віра») - це відносини між юридичними або фізичними особами під час надання один одному цінностей (грошей, майна) на відповідний термін за відповідну плату на умовах повернення [1, с. 32].

Розглядаючи економічну категорію кредиту, науковці виділяють низку основних засад кредиту, які полягають в тому, що:

- кредит - це особливий тип економічних відносин, що базується на взаємній довірі сторін певних відносин;

- економічною основою кредиту є мобілізація й накопичення тимчасово вільних коштів, які згодом становлять позичковий капітал;

- кредитування - це акт передачі в тимчасове користування позичальнику кредитором певної суми капіталу на умовах повернення, добровільності та платності [1, с. 34].

Форма економічних відносин між суб'єктами господарської діяльності та державою, а також населенням та іншими країнами або міжнародними фінансовими організаціями називається публічним кредитом [2, с. 35].

Варто зазначити, що публічний (муніципальний, державний) кредит можна визначити як відносини із залучення публічно-територіальними утвореннями тимчасово вільних коштів фізичних або юридичних осіб на засадах терміновості, відплатності, добровільності, поверненості з метою фінансування інших публічних інтересів, покриття бюджетного дефіциту, виконання завдань і функцій держави та територіальних утворень, які врегульовані правовими нормами [2, с. 58].

Вплив на безперервність процесів виробництва та реалізації продукції $є$ одним із проявів ролі публічного кредиту. Завдяки наданню позикових коштів для задоволення тимчасових потреб відбуваються «припливи» та «відливи» коштів позичальників. Це сприяє подоланню затримки відтворювального процесу, забезпечує безперервність і сприяє його прискоренню [1, с. 60].

Одним із дійових інструментів розвитку процесів інтеграції національної економіки у світову економічну систему є публічний кредит. Процес структурної перебудови та стабілізації вітчизняної економіки практично неможливий без кредитної допомоги світового співтовариства держав [1, с. 44].

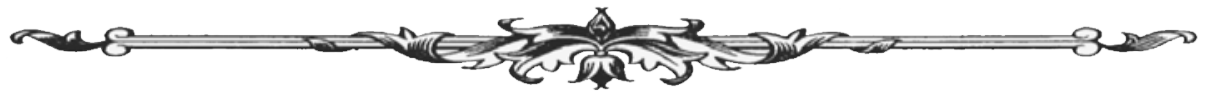


Зростання вагомості ролі публічного кредиту в сучасних умовах відбувається з огляду на інфляцію як постійне явище в економіці держави, а регулювання грошової маси в обігу здійснюється за допомогою кредиту, що забезпечує підтримку стабільної спроможності грошової одиниці [3].

Позитивна роль публічного кредиту проявляється шляхом проведення результативної грошово-кредитної політики, яка в сучасних умовах здебільшого полягає у використанні жорстких заходів із регулювання обсягу грошових і кредитних операцій. Особливо велике значення має захист інтересів позичальників і кредиторів, а також підтримка стійкості та стабільності національної грошової одиниці [1, с. 54].

Зауважимо, що призначення публічного кредиту полягає насамперед у тому, що він є засобом мобілізації в державі додаткових грошових ресурсів. Інакше кажучи, для вирішення проблем у процесі підвищення надходжень бюджету держава використовує беземісійний метод шляхом залучення тимчасово вільних грошових коштів юридичних та фізичних осіб.

Отже, залучені ресурси використовуються для фінансування соціальних і економічних програм держави, а державний кредит, як засіб розширення фінансових можливостей держави, може виступати важливим чинником іiі соціально-економічного розвитку, залучення ж коштів для фінансування загальнодержавних завдань сприяє упорядкуванню грошового обігу [4, с. 243].

Варто зазначити той факт, що як метод мобілізації додаткових грошових коштів державний кредит є досить складним явищем, а віднесення правового інституту публічного кредиту до галузі фінансового права здійснюється на підставі реалізації в цьому режимі функції мобілізації державою грошових коштів на задоволення суспільних потреб [2, с. 94].

Інститут державного кредиту виокремлює норми, які регулюють відносини, що характеризують участь фізичних і юридичних осіб у формуванні централізованих фондів грошових коштів держави та територіальних громад [4, с. 244].

Крім того, державний кредит дозволяє фізичним і юридичним особам із певною економічною вигодою розміщувати особисті грошові кошти в державні цінні папери.

Варто наголосити, що, аналізуючи проблематику публічного кредиту, потрібно звернути увагу на характеристику іншого, похідного від нього явища - державного боргу, адже наявність державних боргових зобов'язань не завжди пов'язана з безвихідною ситуацією в розвитку виробництва.

Водночас унаслідок неконтрольованого використання державного кредиту надмірний державний борг може призвести до серйозних економічних і політичних ускладнень.

Неконтрольоване зростання боргових зобов'язань зумовлює посилення податкового тягаря, додаткові невиробничі витрати, що пов'язані з погашенням боргу й виплатою відсотків по ньому [5, с. 59].

Зазначимо, що правове регулювання публічного кредиту в Україні має певну історію, а економічні та правові основи публічного кредиту закріплені в чинному законодавстві держави.

Неможливо не погодитись із визначенням науковців, які стверджують, що публічний кредит є однією з ланок фінансів України, окремим інститутом фінансового права, предметом якого є сукупність відносин, у яких держава виступає в ролі позичальника, кредитора або гаранта [5, с. 66].

Щодо правового регулювання публічного кредиту, то варто визнати, що до 2010 р. фінансове законодавство містило визначення поняття «кредит», яке полягало в тому, що кредитом визначалися як кошти, так і матеріальні цінності, які надаються резидентами або нерезидентами в користування юридичним або фізичним особам на визначений строк та під процент [5, с. 68].

Саме тому науковці поділяли кредит на: фінансовий, товарний, інвестиційний, податковий і кредит під цінні папери, що засвідчують відносини позики [4, с. 76].

Варто зазначити, що з ухваленням Податкового кодексу України [6] дане визначення втратило чинність, водночас загальне визначення поняття «кредит» не відображено

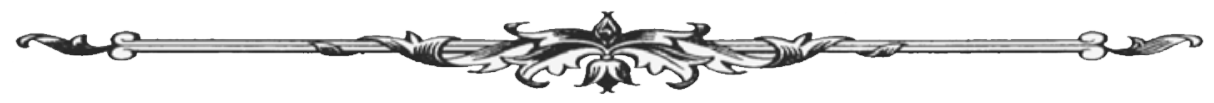


в загальній частині Податкового кодексу України, а є визначення лише податкового кредиту й інших спеціальних понять податкового права.

Немає також визначення публічного кредиту і в Бюджетному кодексі України [7].

Проте варто зазначити, що в нормах Бюджетного кодексу міститься визначення понять державних і місцевих запозичень, зокрема, у ст. 15 Бюджетного кодексу України першими серед джерел фінансування визначені кошти від державних (місцевих) внутрішніх і зовнішніх запозичень, а ст. 16 Бюджетного кодексу України спрямована безпосередньо на врегулювання здійснення відповідних публічних запозичень і управління борговими зобов'язаннями [7].

Правове регулювання бюджетних запозичень відбувається, водночас із загальними конституційними нормами, насамперед положеннями Бюджетного кодексу України, законами України про бюджет та рішеннями органів місцевого самоврядування.

У ст. 2 Бюджетного кодексу України державні запозичення визначені як операції, пов'язані з отриманням державою кредитів (позик) на умовах повернення, платності та строковості з метою фінансування державного бюджету [7].

Варто наголосити, що згідно з бюджетним законодавством поняття «кредит» досить часто порівнюється 3 «позикою», наприклад, «державне запозичення - це операції, пов’язані 3 отриманням державою кредитів (позик)» [4, с. 88], проте бюджетне законодавство додатково та чітко не регулює ці відмінні за своєю юридичною сутністю понятня.

Проте дані поняття, зокрема, відповідно до цивільного законодавства, є відмінними, наприклад, незважаючи на те, що у статтях Цивільного кодексу України зазначено, що до кредитних відносин застосовуються положення правового регулювання договору позики, під кредитом розуміють надання грошових коштів (кредиту), а позикою є як грошові кошти, так і інші речі, визначені родовими ознаками [8].

Основоположними законодавчими актами, які висвітлюють дане питання та регулюють кредитні відносини, є: Цивільний кодекс України [8], закони України «Про банк і банківську діяльність» [9], «Про фінансово-кредитні механізми і управління майном при будівництві житла та операціях з нерухомістю» [10].

Основні засади правового кредитування закріплені у ст. 92 Конституції України, де зазначається: «Виключно законами України встановлюються: < ..> принципи створення та функціонування фінансового, кредитного, грошового та інвестиційного ринку, а також статус національної та іноземної валюти на території України <...>» [11].

Відповідно до Закону України «Про банки і банківську діяльність», Національний банк України (далі - НБУ) видає банкам дозвіл (ліцензію) на видачу кредитів за умови виконання переліку вимог, що затверджені НБУ [9].

Сьогодні не можна не бачити наявних проблем публічного кредитування в умовах ринкової економіки, адже протягом останніх років кредитування здійснюється за таких несприятливих умов, як:

- незадовільний стан економіки загалом;

- занепад промислового виробництва у країні;

- відсутність чинної законодавчої бази, яка б чітко регулювала будь-яке питання [1, c. 67].

Зауважимо, що проблеми публічного кредитування потребують негайного вирішення.

Серед основних заходів, спрямованих на подолання негативних наслідків, можна виділити такі:

- обрати й реалізувати в банківській сфері модель реструктуризації проблемних активів;

- забезпечити відкритість і прозорість інформації, яка стосується обсягів кредитної діяльності;

- створити чітку чинну законодавчу базу, яка не мала б відсилочних норм, а навпаки, чітко б регулювала питання щодо виплати кредиту [2, с. 69].

Варто зазначити, що є низка проблем у правовому регулюванні кредитних операцій, які потребують вирішення. Одна з найгостріших проблем - відсутність єдиного кодифіко-

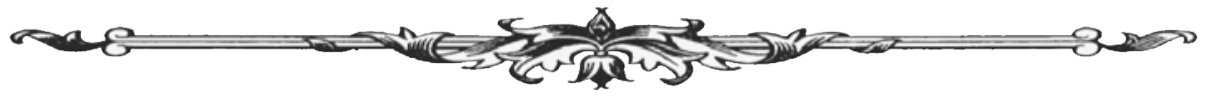


ваного закону, який би чітко регулював усі відносини, що виникають у процесі публічного кредитування.

Висновки. Отже, публічний кредит - це врегульовані правовими нормами відносини щодо залучення тимчасово вільних коштів юридичних і фізичних осіб на принципах добровільності, строковості, відплатності і поверненості з метою покриття державних потреб, який на даний час не передбачає чіткого регулювання законодавчою базою.

Саме тому сфера правового регулювання публічного кредиту потребує як наукового становлення, так і активізації з боку держави, чіткої політичної концепції, відповідної уваги як законодавця, так і уповноважених виконавчих органів, оскільки далеко не останнє місце в системі засобів стимуляції розвитку економіки та здійснення ефективної фінансової діяльності в державі належить публічному кредиту.

Правове регулювання публічного кредиту є необхідним елементом у суспільстві, адже відсутність Банківського кодексу найбільш відчутна в разі виникнення спорів, судового позову, коли йдеться про захист інтересів сторін.

Також немає єдиного нормативного акта для захисту сторін, а наявні прогалини у відсилочних нормах законодавства не пришвидшують розвиток економіки та держави загалом, навпаки, заважають розвитку країни, у якій публічний кредит повинен стати тим джерелом фінансування, що покликане забезпечити активний інноваційний, отже, і економічний та суспільний розвиток держави загалом.

Список використаних джерел: C. $58-60$.

1. Потійко Ю. Ще раз про кредит. Вісник Національного банку України. 2004. № 4.

2. Опря А., Верига Ю., Капаєва Л. Правові засади державного кредиту : навчальний посібник. Київ : Центр навчальної літератури, 2004. 248 с.

3. Нормативно-правове забезпечення відносин у галузі державного кредиту. URL: http://www.ebk.net.ua/Book/FPravo/11-20/11203.htm (дата звернення: 15.11.2019).

4. Зайцева Н. Публічно-правова природа державного кредиту. Проблеми законності. 2008. № 98. С. 243-248.

5. Гетманцев Д. Фінансово-правове зобов'язання як окрема категорія фінансового права : монографія. Київ : Юрінком-Інтер, 2011. 368 с.

6. Податковий кодекс України : Закон України від 2 грудня 2010 р. (зі змінами та доповненнями від 20 жовтня 2019 р.) / Верховна Рада України. URL: https://zakon.rada.gov.ua/laws/ show/2755-17 (дата звернення: 15.11.2019).

7. Бюджетний кодекс України : Закон України від 8 липня 2010 р. (у редакції від 25 вересня 2019 р.) / Верховна Рада України. URL: https://zakon.rada.gov.ua/laws/ show/2456-17 (дата звернення: 14.11.2019).

8. Цивільний кодекс України : Закон України від 16 січня 2003 р. (у редакції від 7 березня 2018 р.) / Верховна Рада України. URL: http://zakon3.rada.gov.ua/laws/show/435 (дата звернення: 15.11.2019).

9. Про банки і банківську діяльність : Закон України (зі змінами та доповненнями від 1 січня 2019 р.) / Верховна Рада України. URL: https://zakon.rada.gov.ua/go/2121-14 (дата звернення: 14.11.2019).

10. Про фінансово-кредитні механізми і управління майном при будівництві житла та операціях з нерухомістю : Закон України (у редакції від 10 червня 2017 р.) / Верховна Рада України. URL: https://zakon.rada.gov.ua/laws/show/978-15 (дата звернення: 15.11.2019).

11. Конституція України, прийнята на п’ятій сесії Верховної Ради України 28 червня 1996 р. Київ : Преса України, 1997. 80 с. URL: http://zakon5.rada.gov.ua/laws/show/254\%D0\%B (дата звернення: 15.11.2019).

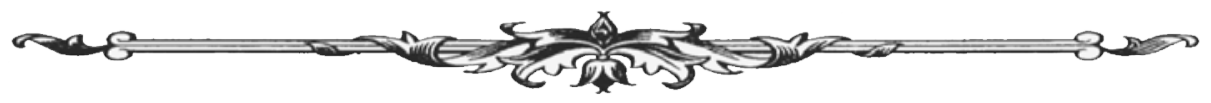

